\title{
Bioavailability of heavy metals in the Guadalete River Estuary (SW Iberian Peninsula)
}

\section{Biodisponibilidad de metales pesados en el Estuario del Río Guadalete (SO Península Ibérica)}

\author{
Olivia Campana \\ Antonio Rodríguez \\ Julián Blasco* \\ Instituto de Ciencias Marinas de Andalucía \\ Campus Río S. Pedro \\ 11510 Puerto Real, Cádiz, España \\ *E-mail: julian.blasco@icman.csic.es
}

Recibido en junio de 2003; aceptado en febrero de 2004

\begin{abstract}
Sediments in the Guadalete River estuary were studied to determine the bioavailability of five common metals (Cu, Zn, $\mathrm{Cd}$, $\mathrm{Pb}$ and $\mathrm{Ni}$ ) in order to evaluate the toxicity of the sediment. Total sediment dry weight concentrations of heavy metals, simultaneously extracted metals (SEM) and acid volatile sulfides (AVS) were analyzed. Interstitial water criteria toxic units (IWCTU) were calculated and used as criteria to evaluate toxicity, making reference to the Sediment Quality Guidelines developed by the US Environmental Protection Agency. Diffusive fluxes through the sediment-water interface were also analyzed. The balance of deposition and return fluxes demonstrated the efficiency of estuarine sediment from Guadalete as sink for metal contaminants. The ratio between SEM and AVS was smaller than one, apparently indicating that the sediment was not toxic; however, the high concentrations of $\mathrm{Cu}$ and $\mathrm{Pb}$ in pore water make further investigations necessary to evaluate the real bioavailability and bioaccumulation of trace metals to show the obviousness of toxicity.
\end{abstract}

Key words: Sediment, bioavailability, metals, SEM, AVS.

\section{Resumen}

Se analizaron los sedimentos del Estuario del Río Guadalete con el fin de determinar la biodisponibilidad de los metales Cu, $\mathrm{Zn}, \mathrm{Cd}, \mathrm{Pb}$ y Ni, y evaluar la toxicidad de los sedimentos. Se analizó la concentración total de metales, los metales extraídos simultáneamente (SEM), y los sulfuros volátiles ácidos (AVS). Para la evaluación de la toxicidad se calcularon y emplearon los criterios de unidades tóxicas para el agua intersticial (IWCTU). Para ello se emplearon las referencias propuestas por las Guías de Calidad de Sedimentos desarrolladas por la Agencia de Protección Ambiental de Estados Unidos (USEPA). También se ha procedido al análisis de los flujos difusivos a través de la interfase agua-sedimento. Los balances de flujo de entrada y salida mostraron la eficiencia de los sedimentos del Estuario del Guadalete como sumidero de contaminación metálica. La proporción entre SEM y AVS fue menor que 1, e indicaba, en principio, que el sedimento no era tóxico. No obstante, las altas concentraciones de $\mathrm{Cu}$ y $\mathrm{Pb}$ en el agua intersticial ponen de manifiesto la necesidad de evaluar la biodisponibilidad real y la bioacumulación de los metales a fin de establecer de manera inequívoca la no toxicidad de los sedimentos.

Palabras clave: Sedimento, biodisponibilidad, metales, SEM, AVS.

\section{Introduction}

Estuaries are very important ecosystems because they undergo numerous chemical and biological processes and they are vital for the growth of several marine species. Nevertheless, too often, these systems are subjected to heavy anthropogenic impact due to agricultural, industrial and urban wastes, and bed sediments act as sink of organic and inorganic contaminants. The adsorbed metals on particulate matter can be desorbed and released into the water column and pore water. In this way, the metals will be uptaken and bioaccumulated by benthic and pelagic organisms. Hence, the measure of

\section{Introducción}

Los estuarios son ecosistemas de gran importancia, ya que en ellos ocurren numerosas reacciones químicas y procesos biológicos, y son además vitales para la cría de especies marinas. No obstante, estos sistemas se encuentran sometidos a un fuerte presión antropogénica derivada del vertido de desechos agrícolas, industriales y urbanos; su lecho actúa como un sumidero de contaminantes orgánicos e inorgánicos. Los metales adsorbidos sobre el material particulado pueden ser desorbidos y liberados a la columna de agua y al agua intersticial. De esta forma, los metales pueden ser incorporados y 
bioavailability and subsequent toxicity of the metals represents the first step to assess the risk of sediment contamination and eventually implement regulatory strategies to limit or prevent additional contamination. Aiming to protect the environment, Sediment Quality Guidelines (SQG) have been developed by the US Environmental Protection Agency in an effort to assess sediment toxicity with broad applicability. However, in view of the complexity of sediment environments, most studies still focus on establishing SQG for specific districts or situations, such as fresh-water and marine sediments (Liu et al., 1999).

Although most studies have tried to evaluate metal bioavailability based primarily on metal concentration in interstitial water, it is critical to bear in mind all possible sources of metal bioavailability and identify the habits of the species studied, i.e., benthic or pelagic species, suspension feeders or detritivors, etc. For instance, it is inappropriate to consider interstitial water as the only route of exposure to contaminants in sediments when organisms that ingest substantial amounts of sediments are studied (Chapman, 1995). Moreover, it is insufficient to predict toxic effects on suspension feeders based on metal bioavailability in interstitial water.

The objective of this study is to determine the bioavailabilty of five common metals ( $\mathrm{Cu}, \mathrm{Zn}, \mathrm{Cd}, \mathrm{Pb}$ and $\mathrm{Ni}$ ), considering different sources of metal bioavailability, and evaluate the toxicity of sediments in the Guadalete River estuary. Total sediment dry weight concentration for each metal was considered and compared with critical values found in the NOAA Screening Quick Reference Tables (SQUIRTs) (Buchman, 1999). With reference to SQG, according to two prevalent approaches, we calculated acid volatile sulfides (AVS) and interstitial water criteria toxic units (IWCTU), proposed by Ankley et al. (1996). Since particle-reactive metals released into estuarine or coastal marine waters can be scavenged by particles and removed to the sediment (deposition flux), or metals can move back up to the overlying water (return diffusion flux) due to digenetic reactions at the sediment-water interface, the balance of deposition and return fluxes is very important to determine the efficiency of estuarine or marine coastal systems as sink for metal contaminants or source of contaminants for the overlying water column (Shine et al., 1998). In consequence, trace metal diffusive fluxes through the sediment-water interface were also calculated.

\section{Material and methods}

\section{Study area}

The Guadalete River flows into the Bay of Cádiz, located in the southwestern Iberian Peninsula (fig. 1). Since the 1960s, this river has been subjected to intense pollution due to discharges of urban, industrial, agricultural and livestock wastes from more than twenty urban centers of nearly 400,000 bioacumulados por los organismos pelágicos y bentónicos. Así, la medida de la biodisponibilidad, y la subsiguiente toxicidad de los metales, representa el primer paso en la evaluación del riesgo que representa la contaminación de los sedimentos, a fin de implementar estrategias de regulación que permitan prevenir la contaminación. Con el fin de establecer umbrales de toxicidad que sean aplicables ampliamente para proteger el medio ambiente, la Agencia de Protección Ambiental de Estados Unidos (USEPA) ha desarrollado las Guías de Calidad de Sedimento (SQGs). No obstante, dada la gran complejidad de los sedimentos, la mayoría de los estudios tratan de establecer SQGs para situaciones o ambientes específicos, como es el caso de medios acuáticos de agua dulce o sedimentos marinos (Liu et al., 1999).

Aunque la mayoría de las investigaciones han tratado de evaluar la biodisponibilidad de los metales en función de su concentración en agua intersticial, es necesario considerar las posibles fuentes de biodisponibilidad de metales e identificar los hábitos de las especies estudiadas, como especies pelágicas, bentónicas, suspensívoras, detritívoras, etc. Así por ejemplo, resulta inapropiado considerar el agua intersticial como la única ruta de exposición de contaminantes en los sedimentos, cuando hay organismos que ingieren una cantidad importante de sedimentos, por lo que esta ruta también debe ser tomada en cuenta (Chapman, 1995). Por tanto, resulta inadecuado predecir los efectos tóxicos en los organismos suspensívoros a partir de la medida de la biodisponibilidad de los metales en el agua intersticial.

El objetivo de este trabajo fue determinar la biodisponibilidad de cinco metales ( $\mathrm{Cu}, \mathrm{Zn}, \mathrm{Cd}, \mathrm{Pb}$ y Ni), teniendo en cuenta las distintas fuentes que contribuyen a ésta, y evaluar la toxicidad de los sedimentos del Estuario del Río Guadalete. En consecuencia, la concentración total de metales en los sedimentos ha sido comparada con los valores guías de las tablas de referencia para el monitoreo de sedimentos (SQUIRTs) de la Administración Nacional de EUA para los Océanos y la Atmósfera (NOAA) (Buchman, 1999). A la hora de hacer referencia a los SQGs se han considerado dos aproximaciones: los sulfuros volátiles ácidos (AVS) y los criterios de unidad tóxica para el agua intersticial (IWCTU) propuestos por Ankley et al. (1996).

Dado que los metales pueden ser atrapados por las partículas en aguas estuáricas o marinas, y ser depositados en el sedimento (flujo de deposición), o bien debido a procesos diagenéticos en la interfase agua-sedimento, éstos pueden pasar al agua sobrenadante (flujo de difusión de retorno), el balance entre ambos flujos es importante a la hora de determinar la eficiencia de un estuario o un ecosistema costero como fuente de contaminantes para la columna de agua sobrenadante (Shine et al., 1998). Por esta razón, los flujos difusivos de metales a través de la interfase agua-sedimento se calcularon con el fin de evaluar su importancia relativa. 


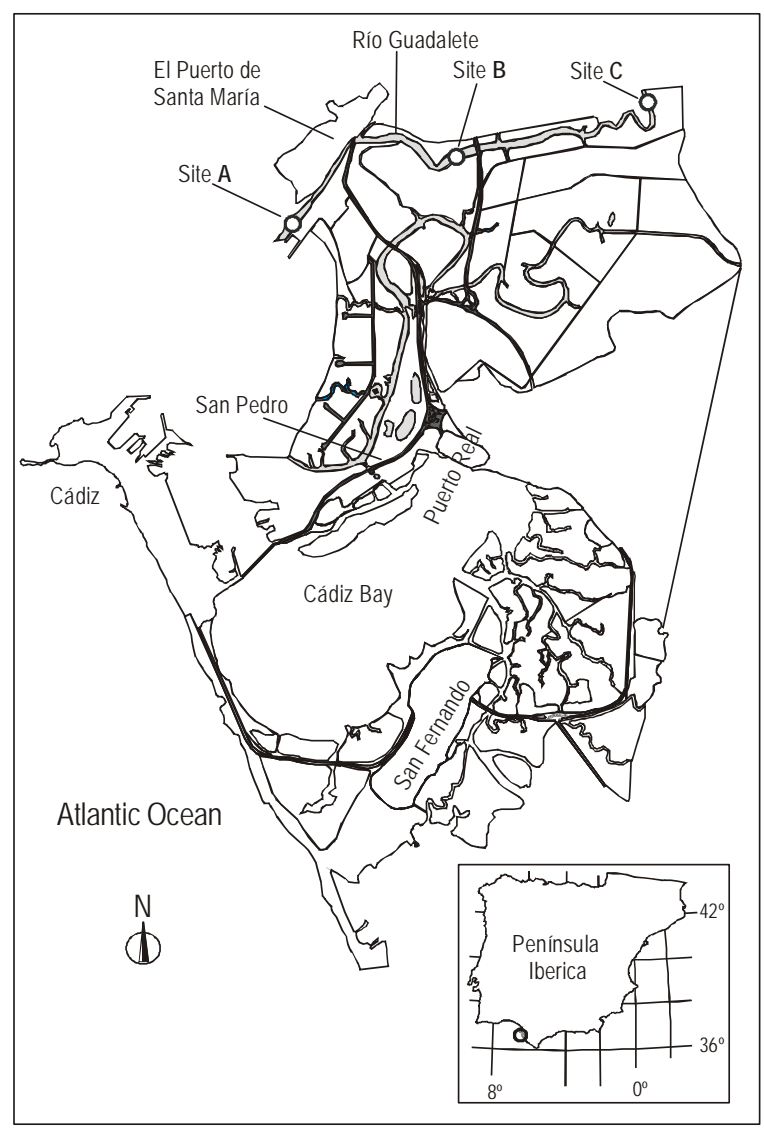

Figure 1. Map of Cádiz Bay and sampling sites located in the Guadalete River estuary (SW Spain).

Figura 1. Mapa de la Bahía de Cádiz en donde se muestran las estaciones de muestreo en el Estuario del Río Guadalete.

inhabitants. The recovery of the Guadalete River began in 1988 with a plan that included the construction of wastedepuration plants along the river to remove the contamination.

The sampling stations were selected in three different environments of the estuary, with a distance of approximately $1 \mathrm{~km}$ between each other. Site A is located near the town of El Puerto de Santa María, in front of the sailing harbor, in an area of commercial traffic, and its substrate is sandier than that of the other stations. Sites B and C were situated more inland, in areas surrounded by crops and salt-marshes. Severe mollusk harvesting occurs at site $\mathrm{B}$. All sediments are anoxic and subject to a tidal regime.

\section{Sample collection and handling}

Sediments were collected in February 2001 and two replicates of sediment cores were taken from each station with a polycarbonate tube core $(5 \mathrm{~cm}$ inner diameter, $50 \mathrm{~cm}$ in length). Immediately after collection, core tubes were kept in the upright position to avoid mixing, sealed in a plastic bag and frozen at $-20^{\circ} \mathrm{C}$ within $3 \mathrm{~h}$ of collection, until analysis. In the laboratory, sediment cores were sub-sampled still frozen, in

\section{Materiales y métodos}

\section{Área de estudio}

El Río Guadalete desemboca en la Bahía de Cádiz que se encuentra localizada en el Suroeste de la Península Ibérica (fig. 1). Desde la década de los sesenta del siglo pasado este río ha sido sometido a una intensa contaminación, debido a descargas urbanas industriales y agrícolas, y al vertido de las aguas residuales de unas veinte ciudades, con una población total en torno a los 400,000 habitantes. En 1988 se comenzó un proceso de recuperación del Río Guadalete mediante un plan que incluía la construcción de plantas depuradoras de aguas residuales a lo largo del río.

Se seleccionaron tres estaciones de muestreo en diferentes zonas del estuario, con aproximadamente $1 \mathrm{~km}$ de distancia entre ellas. La estación A está situada cerca de la ciudad del Puerto de Santa María, delante de un puerto deportivo, en un área con tráfico comercial de embarcaciones, y presenta un sustrato con mayor presencia de arena que las otras dos estaciones. Las estaciones B y C están situadas más en el interior del estuario, y están rodeadas por zonas de cultivos y marismas; en el caso de la estación B, ésta está en un área donde se realizan diversas actividades relacionadas con el marisqueo. Todos los sedimentos se caracterizan por ser anóxicos y estar sometidos a un régimen de mareas semidiurnas.

\section{Recolección de muestras y manejo}

Los sedimentos fueron recogidos en febrero de 2001, tomando dos réplicas de testigos de sedimento con tubos de policarbonato ( $5 \mathrm{~cm}$ de diámetro interior y $50 \mathrm{~cm}$ de longitud). Inmediatamente después de la toma de muestras, los testigos fueron mantenidos en posición vertical en una bolsa de plástico sellada y congelados $\mathrm{a}-20^{\circ} \mathrm{C}$ dentro de las tres horas después de la recolección, hasta el momento del análisis. Una vez en el laboratorio, los testigos sin descongelar, fueron cortados a diferentes profundidades: 0-2, 4-6, 10-12, 20-22 cm, y la sección correspondiente a los dos últimos $\mathrm{cm}$. Cada sección se homogeneizaba rápidamente, y las muestras fueron congeladas hasta el análisis de AVS, o directamente procesadas para el análisis de metales totales o su concentración en el agua intersticial. Las condiciones durante el manejo de las muestras no se mantuvieron anaeróbicas, ya que de acuerdo con los resultados obtenidos por Boothman y Helmstetter (1992), es posible procesar y refrigerar o congelar los sedimentos sin atmósfera de nitrógeno durante un periodo de 14 días sin pérdida de AVS.

\section{Análisis de sedimento}

Se analizaron los AVS, los metales extraídos simultáneamente (SEM), la concentración total de metales y la porosidad. La concentración de AVS fue analizada de acuerdo con el procedimiento descrito por Simpson (2001). Los SEM fueron extraídos mediante la adición de $15 \mathrm{~mL}$ de $\mathrm{HCl}$ al $10 \%$ a aproximadamente $1.5 \mathrm{~g}$ de sedimento húmedo durante 2 horas con agitación contínua. Después de la extracción, las muestras 
five 2-cm thick segments at different depths: 0-2, 4-6, 10-12 and $20-22 \mathrm{~cm}$, and the last $2 \mathrm{~cm}$ of each core. Homogenizing was rapidly performed and sub-samples of sediments were frozen until AVS analysis or directly processed for total digestion and interstitial water determinations. No anaerobic condition was used for the handling or storage of samples, because according to Boothman and Helmstetter (1992), it is possible to process and then refrigerate or freeze sediments without a nitrogen atmosphere for up to 14 days with no loss of AVS.

\section{Sediment analysis}

Sediments were analyzed for AVS, simultaneously extracted metals (SEM), total metal concentration and porosity. The concentrations of AVS in the sediment were analyzed according to the method proposed by Simpson (2001). The SEM were extracted adding $15 \mathrm{~mL}$ of $10 \% \mathrm{HCl}$ to approximately $1.5 \mathrm{~g}$ of wet sediment, for $2 \mathrm{~h}$ with continuous agitation. After extraction, a centrifuge was performed at $3000 \mathrm{~g}$ for 30 min to separate hydrochloric acid extracts from solids (Langston and Spence, 1994).

To determine total metal concentration, approximately $0.20 \mathrm{~g}$ of dry weight sediment was digested by microwaves, following the method described by Loring and Rantala (1992). SEM and total metal concentration were analyzed by graphite furnace (GFAAS, PE 4100ZL), with Zeeman background correction and appropriate matrix modifiers. Blanks were run with each batch of analysis. Samples of a reference estuarine sediment (BCR n.277) were also analyzed, simultaneously with all metal analysis, to determine the analytical accuracy. Accuracy for samples ranged from 70\% to 99\%. Merck Suprapur reagents were used in all cases. Porosity of the sediment $(\Phi)$ was measured as the loss in weight by desiccation.

\section{Pore water analysis}

Pore water was extracted by centrifugation at 48,000 $\mathrm{g}$ for $1 \mathrm{~h}$ at $4^{\circ} \mathrm{C}$ using a Beckman J2-21 centrifuge. The pore water samples obtained were kept in an acid environment by adding ultra-pure $\mathrm{HCl}, 1 \%(\mathrm{v} / \mathrm{v})$. The determination of $\mathrm{Zn}, \mathrm{Cd}, \mathrm{Pb}$ and $\mathrm{Cu}$ was made with anodic stripping voltammetry using Metrohm equipment (VA 746 Trace Analyzer) over a 10-mL volume of sample (Ponce et al., 2000). To avoid the interference in the analytical signals due to the presence of the organic matter in the pore water samples, the oxidation of organic matter was conducted with UV radiation digestion (Metrohm, $705 \mathrm{UV}$ ), at $80-90^{\circ} \mathrm{C}$ with $1 \% \mathrm{H}_{2} \mathrm{O}_{2}$ for $90 \mathrm{~min}$.

\section{Sediment quality criteria}

As proposed by Ankley et al. (1996), the bioavailability of metals in the sediments was predicted, following Sediment Quality Criteria (SQC) based on AVS criteria and IWCTU. Because metals act in a competitive manner when binding to AVS, e.g., in the order of increasing solubility, they must be considered together. Likewise, regarding their possible toxic se centrifugaron a $3000 \mathrm{~g}$ durante $30 \mathrm{~min}$, con el fin de separar los extractos ácidos de los sólidos (Langston y Spence, 1994).

Para determinar la concentración total de metales, aproximadamente $0.20 \mathrm{~g}$ de sedimento seco fueron digeridos con microondas, siguiendo el procedimiento descrito por Loring y Rantala (1992). Los SEM y la concentración total de metales fueron analizados por espectrofotometría de absorción atómica con horno de grafito y corrección por efecto Zeeman longitudinal (GFAAS, PE 4100 ZL) con los modificadores apropiados. Para cada grupo de muestras se llevaron blancos en paralelo. Con el fin de establecer la exactitud de los resultados, éstos fueron verificados mediante el empleo de material de referencia de sedimentos estuáricos (BCR n.277), el cual fue analizado simultáneamente con todos los análisis de metales. La exactitud de los resultados varió entre 70 y 99\%. En todos los casos se emplearon reactivos de calidad Merck Suprapur. La porosidad del sedimento $(\Phi)$ fue medida como la pérdida de peso por secado.

\section{Análisis de agua intersticial}

El agua intersticial fue extraída por centrifugación a $48000 \mathrm{~g}$ durante $1 \mathrm{~h} \mathrm{a} 4^{\circ} \mathrm{C}$, con una centrífuga Beckman J2-21. Las muestras se acidificaron con $\mathrm{HCl}$ al $1 \%$ (v/v). La determinación de $\mathrm{Zn}, \mathrm{Cd}$, Pb y Cu se realizó con volta-amperometría de redisolución anódica (ASV) con un equipo Metrohm (VA 746 Trace Analyzer) sobre un volumen de muestra de $10 \mathrm{~mL}$ (Ponce et al., 2000). Con el fin de evitar las interferencias derivadas de la presencia de materia orgánica, la oxidación de ésta se llevó a cabo mediante radiación UV (Metrohm, 705 UV) a 80- $90^{\circ} \mathrm{C}$ con $\mathrm{H}_{2} \mathrm{O}_{2}$ al $1 \%$ durante 90 min.

\section{Criterios de calidad de sedimentos}

Ankley et al. (1996) propusieron que la biodisponibilidad de los metales presentes en los sedimentos se podía predecir, siguiendo Criterios de Calidad de Sedimentos (SQC) basados en el criterio de AVS y en IWCTU. Debido a que los metales actúan de manera competitiva cuando se enlazan a los AVS, por ejemplo, en el orden de su incremento de solubilidad, éstos deben ser considerados de manera conjunta. Igualmente, en cuanto a sus posibles interacciones tóxicas, las concentraciones de los metales en agua intersticial se convierten en unidades tóxicas, y deben ser sumadas. El hecho de que algunos sedimentos que superan los SQC no tengan efecto o impacto sobre los organismos, debe ser consecuencia de que se satisfacen las condiciones siguientes:

\section{(a) Criterios AVS}

para un metal: $[\mathrm{SEM}] \leq[\mathrm{AVS}]$

para varios metales: $\sum_{i}\left[\mathrm{SEM}_{i}\right] \leq[\mathrm{AVS}]$

(b) Criterios para agua intersticial

para un metal: $\left[\mathrm{M}_{\mathrm{d}}\right] \leq\left[\mathrm{FCV}_{\mathrm{d}}\right]$ y IWCTU $=\frac{\left[\mathrm{M}_{\mathrm{d}}\right]}{\left[\mathrm{FCV}_{\mathrm{d}}\right]}$ 
interactions, the interstitial water metal concentrations are converted into toxic units and these are summed. When sediments exceed the SQC and have no effect or biological impact on organisms, all of the following conditions are satisfied:

\section{(a) AVS criteria}

for single metal: [SEM] $\leq$ [AVS ]

for multiple metals: $\sum_{i}\left[\mathrm{SEM}_{i}\right] \leq[\mathrm{AVS}]$

(b) Interstitial water criteria

for single metal: $\left[\mathrm{M}_{\mathrm{d}}\right] \leq\left[\mathrm{FCV}_{\mathrm{d}}\right]$ and IWCTU $=\frac{\left[\mathrm{M}_{\mathrm{d}}\right]}{\left[\mathrm{FCV}_{\mathrm{d}}\right]}$ for multiple metals: $\sum_{i} \frac{\left[\mathrm{M}_{i, \mathrm{~d}}\right]}{\left[\mathrm{FCV}_{i, \mathrm{~d}}\right]} \leq 1$

where [SEM] is the concentration of simultaneously extracted metal, [AVS] is the concentration of acid volatile sulfides, $\left[M_{d}\right]$ is the total dissolved interstitial water concentration of metal and $\left[\mathrm{FCV}_{\mathrm{d}}\right]$ is the final chronic value of metal applied to total dissolved metal concentration. We calculated the FCV from Criteria Continuous Concentration (CCC) recommended by SQUIRTs, for trace elements in Ambient Water Quality Criteria (AWQC) (Buchman, 1999). The CCC values for $\mathrm{Cu}, \mathrm{Zn}, \mathrm{Pb}$ and $\mathrm{Cd}$ are shown in table 1 . In order to establish the relative affinity of metals for solid phase, the partition coefficient for each metal $\left(\mathrm{K}_{i}\right)$ was calculated as follows:

$$
\mathrm{K}_{i}=\frac{\mathrm{C}_{s, i}}{\mathrm{C}_{\mathrm{iw}, i}}
$$

where $\mathrm{C}_{\mathrm{s}, i}$ and $\mathrm{C}_{\mathrm{iw}, i}$ represent the total concentration of the $i$ th metal in the solid phase and in interstitial water, respectively. Because of the molar stoichiometry of metal binding to AVS, the solid-phase constituents (AVS, SEM) are expressed in $\mu$ mol g ${ }^{-1}$ dry weight. The interstitial water metal concentrations are expressed in $\mu \mathrm{mol} \mathrm{L}^{-1}$ and the partition coefficients are in $\mathrm{L}$ pore water $\mathrm{g}^{-1}$ dry weight.

\section{SQUIRTs for trace elements in marine sediment}

Total metal dry weight concentrations were compared with marine sediment screening values reported by NOAA SQUIRTs, which are associated with several probabilities of adverse biological effects. Threshold Effect Levels (TELs) represent the level below which adverse effects are expected to occur only rarely. Conversely, they do not predict toxicity. The Effect Range Low (ERL) represents the value at which toxicity may begin to be observed in sensitive species. Probable Effect Levels (PELs) are the concentration above which adverse effects are frequently expected (Buchman, 1999). para varios metales: $\sum_{i} \frac{\left[\mathrm{M}_{i, \mathrm{~d}}\right]}{\left[\mathrm{FCV}_{i, \mathrm{~d}}\right]} \leq 1$

donde [SEM] es la concentración de los metales extraídos simultáneamente y [AVS] es la concentración de los sulfuros volátiles ácidos, $\left[\mathrm{M}_{\mathrm{d}}\right]$ es la concentración total de metales disueltos en el agua intersticial, y $\left[\mathrm{FCV}_{\mathrm{d}}\right]$ es el valor de toxicidad crónica aplicado al conjunto de los metales totales disueltos. El cálculo de FCV para los Criterios de Concentración Contínua (CCC) recomendados por SQUIRTs para los elementos trazas se basa en los Criterios de Calidad para el Agua Ambiental (AWQC) (Buchman, 1999). Los valores de CCC para $\mathrm{Cu}, \mathrm{Zn}, \mathrm{Pb}$ y Cd se muestran en la tabla 1 . Con el fin de establecer la afinidad relativa de los metales para la fase sólida, los coeficientes de partición para cada metal $\left(\mathrm{K}_{i}\right)$ se calculan como sigue:

$$
\mathrm{K}_{i}=\frac{\mathrm{C}_{s, i}}{\mathrm{C}_{\mathrm{iw}, i}}
$$

donde $\mathrm{C}_{\mathrm{s}, i} \mathrm{y} \mathrm{C}_{\mathrm{iw}, i}$ corresponden a las concentraciones totales del metal $i$ en la fase sólida y en el agua intersticial, respectivamente. Debido a la estequiometría molar de los metales que se enlazan a los AVS, los constituyentes de la fase sólida (AVS, SEM) son expresados en $\mu$ mol g-1 peso seco. Las concentraciones de metales en el agua intersticial son expresadas en $\mu \mathrm{mol} \mathrm{L} \mathrm{L}^{-1} \mathrm{y}$ los coeficientes de partición están expresados en $\mathrm{L}$ agua intersticial g ${ }^{-1}$ peso seco.

\section{SQUIRTs para elementos trazas en los sedimentos marinos}

La concentración total de los metales, expresada en peso seco, se comparó con los valores para el monitoreo de sedimentos registrados por las SQUIRTs de NOAA, y los cuales se asocian con varias posibilidades de efectos adversos sobre los organismos. Así, los niveles de efecto umbral (TELs) representan el nivel por debajo del cual es de esperarse que rara vez ocurran efectos adversos. Si bien cuando se considera de manera inversa, estos valores no predicen toxicidad. El

Table 1. Ambient Water Quality Criteria for selected metals proposed in NOAA Screening Quick Reference Tables for inorganic compounds in surface marine water (Buchman, 1999).

Tabla 1. Criterios de Calidad del Agua Ambiental para metales selectos propuestos en las tablas de referencia para el monitoreo de compuestos inorgánicos en aguas marinas superficiales de la NOAA.

\begin{tabular}{cc}
\hline Metals & $\begin{array}{c}\text { Criteria Continuous Concentration } \\
\text { “chronic” (ppb) }\end{array}$ \\
\hline $\mathrm{Cu}$ & 3.1 \\
$\mathrm{~Pb}$ & 8.1 \\
$\mathrm{Zn}$ & 81 \\
$\mathrm{Cd}$ & 9.3 \\
\hline
\end{tabular}




\section{Diffusive fluxes}

Benthic fluxes of a dissolved species through the sedimentwater interface, due to molecular diffusion, were estimated applying Fick’s first law:

$$
\mathrm{J}=-\Phi \times \mathrm{D}_{\mathrm{s}} \times\left|\frac{\partial \mathrm{C}}{\partial \mathrm{z}}\right|_{\mathrm{z}=0}
$$

where $\mathrm{J}$ is the diffusive flux, $\Phi$ is the porosity and $\left|\frac{\partial \mathrm{C}}{\partial \mathrm{z}}\right|$ is the concentration gradient between the concentration of the dissolved species in the pore water in the upper layer of the sediment and that in the overlying water column. Since the remobilization took place in the upper layer of the sediment, a linear fit of the concentration of trace metals in the pore water at different depths was used to calculate the concentration gradients of trace metals between the pore waters and the overlying waters. Calculated from Sweerts et al.'s (1991) empirical equation, $\mathrm{D}_{\mathrm{s}}$ is the sediment diffusion coefficient:

$$
\mathrm{D}_{\mathrm{s}}=\mathrm{D}^{\mathrm{o}} \times(-0.73 \times \Phi+2.17)^{-1}
$$

where $\mathrm{D}^{\mathrm{o}}$ is the diffusion coefficient to infinite dilution. For $\mathrm{Zn}, \mathrm{Cd}, \mathrm{Pb}$ and $\mathrm{Cu}$, the values of $\mathrm{D}^{\circ}$ used were those described by Li and Gregory (1974) for a temperature of $18^{\circ} \mathrm{C}$.

Statistics

A $p$-Pearson correlation was performed with Statistica 5.0 computer software; $P<0.05$ was used to statistically determine the significance.

\section{Results and discussion}

\section{SEM/AVS ratio}

The SEM, AVS and IWCTU concentration values for each metal and for all sites and depths are reported in table 2 . The depth variation showed that SEM concentration was lower than AVS concentration, except in the first $5 \mathrm{~cm}$ of the superficial sediment of site B, although the difference between AVS and SEM concentrations is very small. Depth profiles of AVS concentrations showed a similar trend. The concentrations of AVS increased with depth, reaching a maximum at approximately $10 \mathrm{~cm}$. Most reports and several studies (Di Toro et al., 1996; Peterson et al., 1996; Yu et al., 2001) indicate that surface concentrations of AVS are smaller than in deeper sediments, because in the upper sediment, AVS, formed by anaerobic oxidation of organic matter, are exposed to bio-irrigation, porewater mixing and bioturbation that cause aerobic oxidation of the sulfide, thus increasing the rate of AVS depletion. Sites B and $\mathrm{C}$ showed similar sediment characteristics for organic matter content and percentage of fine-fraction (silt and clay) (table 3); however, at site C, AVS concentration reached 20.2 $\mu \mathrm{mol} \mathrm{g}{ }^{-1}$, while at site $B$, the maximum value was $1.3 \mu \mathrm{mol} \mathrm{g}{ }^{-1}$. intervalo bajo de efecto (ERL), representa el rango de valores en el cual se empieza a observar toxicidad en especies sensibles. Los niveles de efecto probable (PELs) corresponden a las concentraciones por encima de las cuales deben esperarse efectos adversos frecuentes.

\section{Flujos difusivos}

Los flujos bentónicos para una especie disuelta en la interfase agua-sedimento, debido a la difusion molecular, se estimaron mediante la aplicación de la primera ley de Fick:

$$
\mathrm{J}=-\Phi \times \mathrm{D}_{\mathrm{s}} \times\left|\frac{\partial \mathrm{C}}{\partial \mathrm{z}}\right|_{\mathrm{z}=0}
$$

donde J es el flujo difusivo, $\Phi$ es la porosidad y, $\left|\frac{\partial \mathrm{C}}{\partial \mathrm{z}}\right|$ es el gradiente de concentración entre la concentración de la especie disuelta en el agua intersticial de la capa superficial de sedimento y la del agua sobrenadante. Debido a que los procesos de removilización del sedimento tienen lugar en su capa superficial, se empleó un ajuste lineal de la concentración de los metales trazas en el agua intersticial a diferentes profundidades para el cálculo de los gradientes de concentración entre el agua intersticial y el agua sobrenadante. El coeficiente de difusión del sedimento, $\mathrm{D}_{s}$, se calculó a partir de la ecuación empírica de Sweerts et al. (1991):

$$
\mathrm{D}_{\mathrm{s}}=\mathrm{D}^{\mathrm{o}} \times(-0.73 \times \Phi+2.17)^{-1}
$$

donde $\mathrm{D}^{\circ}$ es el coeficiente de difusión a dilución infinita. Para $\mathrm{Zn}, \mathrm{Cd}, \mathrm{Pb}$ y Cu, los valores de $\mathrm{D}^{\circ}$ empleados son los descritos por Li y Gregory (1974) para una temperatura de $18^{\circ} \mathrm{C}$.

\section{Análisis estadístico}

El coeficiente de correlación de $p$-Pearson se estimó con el programa estadístico Statistica 5.0, empleando un valor de $P<0.05$ para determinar la significancia estadística de los resultados.

\section{Resultados y discusión}

\section{Proporción SEM-AVS}

Los valores de concentración de SEM, AVS e IWCTU para cada metal y en todos los lugares y profundidades se muestran en la tabla 2. La variación con la profundidad mostró que la concentración de SEM era inferior que la de AVS, excepto en los primeros $5 \mathrm{~cm}$ de los sedimentos superficiales de la estación B, aunque las diferencias entre las concentraciones de AVS y SEM eran muy pequeñas. Los perfiles de la concentración de AVS con la profundidad mostraron una tendencia similar, en la que la concentración de AVS se incrementaba con la profundidad alcanzando un máximo a los $10 \mathrm{~cm}$. La mayoría 
Campana et al.: Bioavailability of heavy metals in the Guadalete River estuary

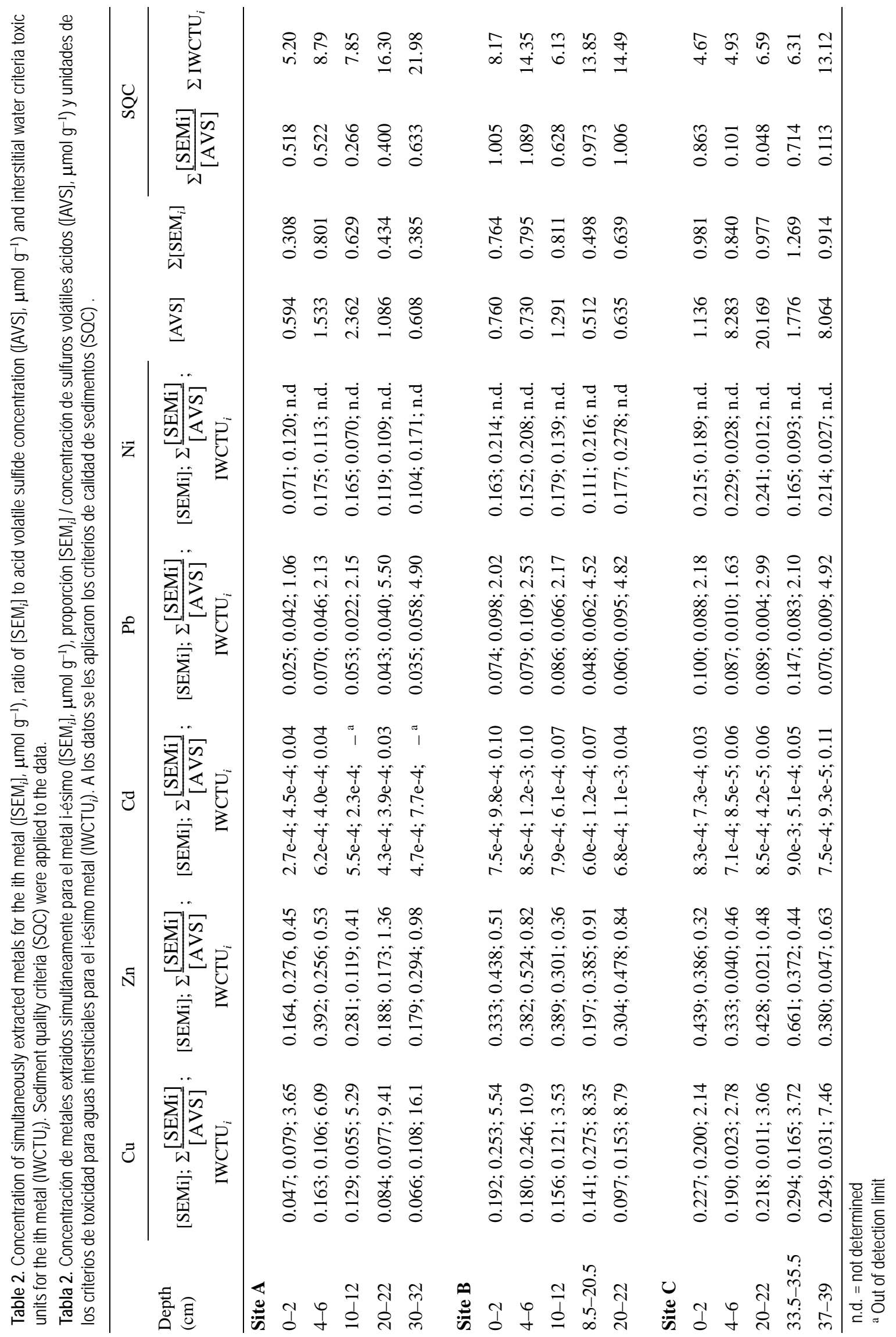


This difference may be due to the intense activity of mollusk harvesting that could increase penetration of oxygen and, together with bio-irrigation, may lead to oxidation of the sulfide. Moreover, the lower anoxic condition of the surface sediment at site B (table 3) could control AVS concentration as indicated by Gonzalez (1996), who reported that redox potentials appear to be inversely related to AVS concentrations, even if this covariation is weak, especially when AVS is $<4 \mu \mathrm{mol} \mathrm{g}{ }^{-1}$ dry weight. At site A, the low concentrations of AVS can be associated with low organic matter content, as well as with the low concentrations of total extracted heavy metals (table 3). This could be due to different sedimentary characteristics, since they show a high percentage of the sandy fraction, known to be poor in binding metals compared with silt or clay.

\section{Pore water profiles}

The vertical profiles of $\mathrm{Zn}, \mathrm{Cd}, \mathrm{Cu}$ and $\mathrm{Pb}$ in the pore water at each site are presented in figure 2. At site B, in the upper sediment that presented the highest SEM/AVS ratios and de los datos de la literatura científica (Di Toro et al., 1996; Peterson et al., 1996; Yu et al., 2001) indican que las concentraciones superficiales de AVS son menores que las de los sedimentos más profundos, ya que en los sedimentos superficiales, los AVS, formados por oxidación anaeróbica de la material orgánica, son expuestos a la bio-irrigación, a la mezcla del agua intersticial y a la bioturbación, que provocan la oxidación aeróbica de los sulfuros $\mathrm{y}$, en consecuencia, la disminución de los AVS. Las estaciones B y C mostraron características similares para el contenido de materia orgánica de los sedimentos y del porcentaje de la fracción limo-arcilla (tabla 3). Sin embargo, en la estación C la concentración de AVS alcanzó un valor de $20.2 \mu \mathrm{mol} \mathrm{g}^{-1}$, mientras que en la estación B el valor máximo fue $1.3 \mu \mathrm{mol} \mathrm{g}^{-1}$. Esta diferencia se puede relacionar con la intensa actividad de marisqueo que tiene lugar en esta última estación y que podría facilitar el incremento de la penetración de oxígeno. Ésta, junto con la bioirrigación, puede dar lugar a la oxidación de los sulfuros. Más aún, las condiciones anóxicas limitadas de los sedimentos superficiales de la estación B (tabla 3) podrían controlar la

Table 3. Physicochemical parameters of sediments from the Guadalete River estuary.

Tabla 3. Parámetros fisicoquímicos de los sedimentos del Río Guadalete.

\begin{tabular}{|c|c|c|c|c|c|c|}
\hline Depth & $\begin{array}{l}\text { Total Extracted } \\
\text { Heavy Metals } \\
\qquad\left(\mu \mathrm{g} \mathrm{g}^{-1}\right)\end{array}$ & $\begin{array}{c}\text { MO } \\
\text { content } \\
(\%)\end{array}$ & $\Phi$ & $\begin{array}{c}\text { Redox potential }^{\mathrm{a}} \\
\text { Eh }(\mathrm{mV})\end{array}$ & $\begin{array}{c}\mathrm{pH}^{\mathrm{a}} \\
\text { sediment }\end{array}$ & $\begin{array}{c}<63 \mu \mathrm{m}^{\mathrm{b}} \\
\text { fraction }(\%)\end{array}$ \\
\hline Site A & & & & -280 & 7.20 & 24.1 \\
\hline $0-2$ & 42.7 & 3.2 & 0.20 & & & \\
\hline $4-6$ & 60.6 & 2.7 & 0.43 & & & \\
\hline 10-12 & 55.2 & 2.9 & 0.32 & & & \\
\hline $20-22$ & 41.6 & 3.3 & 0.23 & & & \\
\hline 30-32 & 47.9 & 3.6 & 0.28 & & & \\
\hline Site B & & & & -118 & 6.62 & 83.2 \\
\hline $0-2$ & 111.1 & 8.8 & 0.43 & & & \\
\hline $4-6$ & 136.2 & 6.7 & 0.34 & & & \\
\hline $10-12$ & 137.7 & 6.4 & 0.33 & & & \\
\hline 18.5-20.5 & 102.0 & n.d. & 0.30 & & & \\
\hline $20-22$ & 137.2 & 5.1 & 0.29 & & & \\
\hline Site C & & & & -213 & 6.93 & 93.7 \\
\hline $0-2$ & 155.4 & 8.4 & 0.64 & & & \\
\hline $4-6$ & 136.4 & 7.7 & 0.48 & & & \\
\hline $10-12$ & 148.6 & 5.0 & 0.54 & & & \\
\hline 33.5-35.5 & 184.8 & n.d. & 0.48 & & & \\
\hline 37-39 & 125.5 & n.d. & 0.34 & & & \\
\hline
\end{tabular}

a Value for superficial sediment.

${ }^{\mathrm{b}}$ Average calculations over $20 \mathrm{~cm}$ depth. 
highest pore water metal concentrations, the concentrations for $\mathrm{Zn}, \mathrm{Pb}$ and $\mathrm{Cu}$ in the interstitial water appeared inversely correlated to the AVS concentrations (at $P<0.05, r_{\mathrm{Zn}}=-0.89$, $r_{\mathrm{Pb}}=-0.74, r_{\mathrm{Cu}}=-0.66$ ). If SQC are applied, sediments pass the first condition (AVS criteria), except at site B, depending on the degree of accuracy. Nevertheless, even though the binding capacity of AVS with metals was not totally exploited, metals were remobilized into pore water and all three sediments violated the second condition (interstitial water criteria). The IWCTU were especially elevated for $\mathrm{Cu}$ and $\mathrm{Pb}$ and shot up इIWCTU values (table 2).

\section{SQUIRTS}

The elevated $\mathrm{Cu}$ concentrations in pore water reflected the high $\mathrm{Cu}$ levels in sediment, which for sites $\mathrm{B}$ and $\mathrm{C}$ exceeded the Threshold Effect Levels proposed by NOAA (fig. 3). Also, total dry weight concentration for $\mathrm{Ni}$ showed values higher than the Effect Range Low for site B, around $40 \mu \mathrm{g} \mathrm{g}^{-1}$, and near the Probable Effect Level value proposed for site $\mathrm{C}$ (fig. 3). Comparison of $\mathrm{Cu}, \mathrm{Pb}, \mathrm{Cd}$ and $\mathrm{Zn}$ total dry weight concentrations, in the solid phase, showed that the concentrations were lower than those reported in others studies for surface sediments located in the southern part of the Bay of Cádiz (Ponce et al., 2000). Nevertheless, metals had higher bioavailability. This large bioavailability may be due to a great affinity of metals for the aqueous phase, reflected by the small values of partitioning coefficients, $K_{\mathrm{D}}$ (table 4), lower than those reported by Liu et al. (1999) for fresh-water sediments strongly impacted by local mining activities in the Le An River region. Especially in the case of $\mathrm{Pb}, K_{\mathrm{D}}$ was below one order of magnitude compared with the minimum value reported by concentración de AVS, como ha sido puesto de manifiesto por Gonzalez (1996), quien registró que los potenciales redox parecen estar relacionados inversamente con la concentración de AVS, incluso si esta covariación es débil, en concreto en aquellos casos en que AVS $<4 \mu \mathrm{mol} \mathrm{g}^{-1}$ peso seco. En la estación A, las bajas concentraciones de AVS pueden estar asociadas con el bajo contenido en materia orgánica, así como con las bajas concentraciones de metales pesados totales extraidos (tabla 3). Esto puede ser consecuencia de las diferentes características sedimentarias, dado el alto porcentaje de la fracción arena, la cual tiene menor capacidad para enlazar metales en comparación con la de la fracción limo-arcilla.

\section{Perfiles del agua intersticial}

En la figura 2 se muestran los perfiles verticales de Zn, Cd, $\mathrm{Cu}$ y $\mathrm{Pb}$ en el agua intersticial para cada estación de muestreo. En la estación B, en la capa más superficial del sedimento se presentan las relaciones SEM/AVS más altas, las concentraciones de metales en el agua intersticial fueron las más elevadas y las concentraciones de $\mathrm{Zn}, \mathrm{Pb}$ y $\mathrm{Cu}$ en el agua intersticial estuvieron correlacionadas inversamente con la concentración de AVS (para $P<0.05, r_{\mathrm{Zn}}=-0.89, r_{\mathrm{Pb}}=-0.74, r_{\mathrm{Cu}}=-0.66$ ). Si se aplican los SQC, los sedimentos satisfacen la primera condición (criterios AVS), dependiendo del grado de exactitud, excepto en la estación B. No obstante, aunque la capacidad de los AVS para unirse a los metales no haya sido superada, los metales pueden ser removilizados al agua intersticial, y los tres sedimentos satisafacerían la segunda condición (criterios para el agua intersticial). Los valores de IWCTU para $\mathrm{Cu}$ y $\mathrm{Pb}$ fueron particularmente elevados y dispararon los valores de

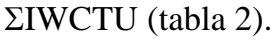
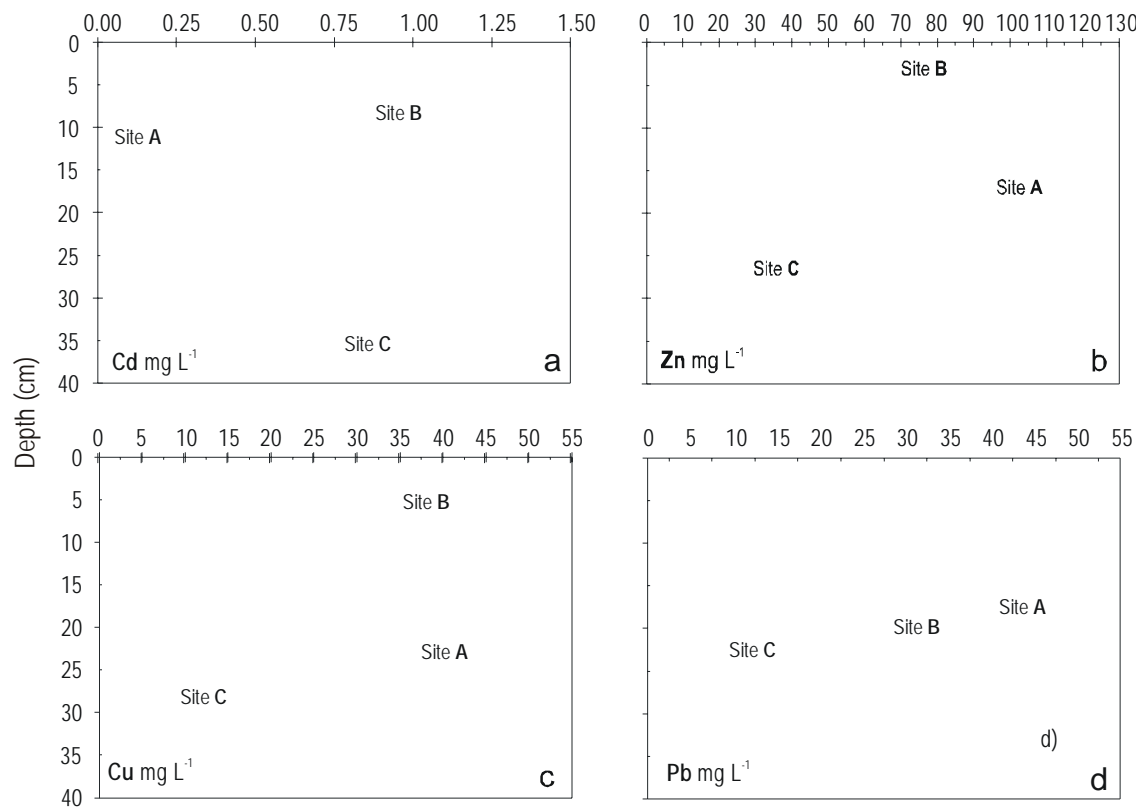

Figure 2. Vertical profiles of the concentrations of (a) $\mathrm{Cd}$, (b) $\mathrm{Zn},(\mathbf{c}) \mathrm{Pb}$ and (d) $\mathrm{Cu}$, in the interstitial water of sites $\mathrm{A}, \mathrm{B}$ and $\mathrm{C}$. Figura 2. Perfiles verticiales de las concentraciones de (a) $\mathrm{Cd}$, (b) $\mathrm{Zn}$, (c) $\mathrm{Pb}$ and (d) $\mathrm{Cu}$, en el agua intersticial de las estaciones $\mathrm{A}, \mathrm{B}$ y $\mathrm{C}$. 
Liu et al. (1999). Based on $K_{\mathrm{D}}$ values, the sequence of affinity of the metals for the aqueous-phase, for all three sites, was: $\mathrm{Cd}>\mathrm{Pb}>\mathrm{Zn}>\mathrm{Cu}$. On the other hand, even in sediments where concentrations of AVS are significant, other partitioning phases may provide additional binding capacity for SEM. In anaerobic sediments, organic carbon appears to be an additional binding phase controlling metal partitioning, in particular for Cd, Cu and Pb (Ankley et al., 1996). Consequently, the presence of elevated concentrations of particulate organic carbon in the interstitial water, characteristic of estuarine systems (Morris, 1985), may explain the high concentrations of $\mathrm{Cu}$ and $\mathrm{Pb}$ for unfiltered pore water samples.

\section{Bioavailability and toxicity}

Even considering the relatively large bioavailability of trace metals in pore water, especially $\mathrm{Pb}$ and $\mathrm{Cu}$, this does not mean that the sediments are toxic, since the water quality criteria are not expressed based on metal activity but on an approximation to this condition (final chronic value), and a substantial number of experiments suggest that biological effects are often correlated to the divalent metal activity, the only bioavailable form (Ankley et al., 1996). Another reason is associated with equilibrium assumption of SQC. This theory assumes that pore water is in equilibrium with the sediment. If the sediment is anoxic and therefore toxic, pore water does not meet the water quality standards. Also, based on this assumption, in presence of AVS, there is no oxygen available

\section{SQUIRTS}

Las elevadas concentraciones de $\mathrm{Cu}$ en el agua intersticial reflejaron los elevados niveles que presentaba este metal en el sedimento. Así, en las estaciones B y C se superaron los TELs propuestos por NOAA (fig. 3). También en el caso del Ni para las concentraciones totales, los valores fueron superiores al ERL en la estación B, con una concentración de $40 \mu \mathrm{g} \mathrm{g}^{-1}$, y próximos a los valores propuestos como PEL para la estación $\mathrm{C}$ (fig. 3). Las concentraciones totales de $\mathrm{Cu}, \mathrm{Pb}, \mathrm{Cd}$ y $\mathrm{Zn}$ halladas en los sedimentos de estas estaciones fueron menores que las encontradas por otros autores en sedimentos de la zona sur de la Bahía de Cádiz (Ponce et al., 2000). No obstante, los metales tenían una mayor biodisponibilidad, lo que fue consecuencia de la gran afinidad que tenían por la fase acuosa y que se refleja en los valores pequeños del coeficiente de partición $\mathrm{K}_{\mathrm{D}}$ (tabla 4), que a su vez son inferiores a los descritos por Liu et al. (1999) para sedimentos de ecosistemas de agua dulce afectados por el impacto de la actividad minera en la región del Río Le An. Especialmente en el caso del $\mathrm{Pb}$, el valor de $\mathrm{K}_{\mathrm{D}}$ era inferior en un orden de magnitud en comparación con los valores mínimos de Liu et al. (1999). En base a los valores de $\mathrm{K}_{\mathrm{D}}$, la secuencia de la afinidad de los metales en fase acuosa en las tres estaciones de muestreo fue: $\mathrm{Cd}>\mathrm{Pb}>\mathrm{Zn}>\mathrm{Cu}$. Por otro lado, incluso en los sedimentos en los que las concentraciones de AVS eran importantes, otras fases pueden representar una fracción importante en la capacidad de enlazar SEM. En sedimentos anaeróbicos el carbono orgánico parece ser una de

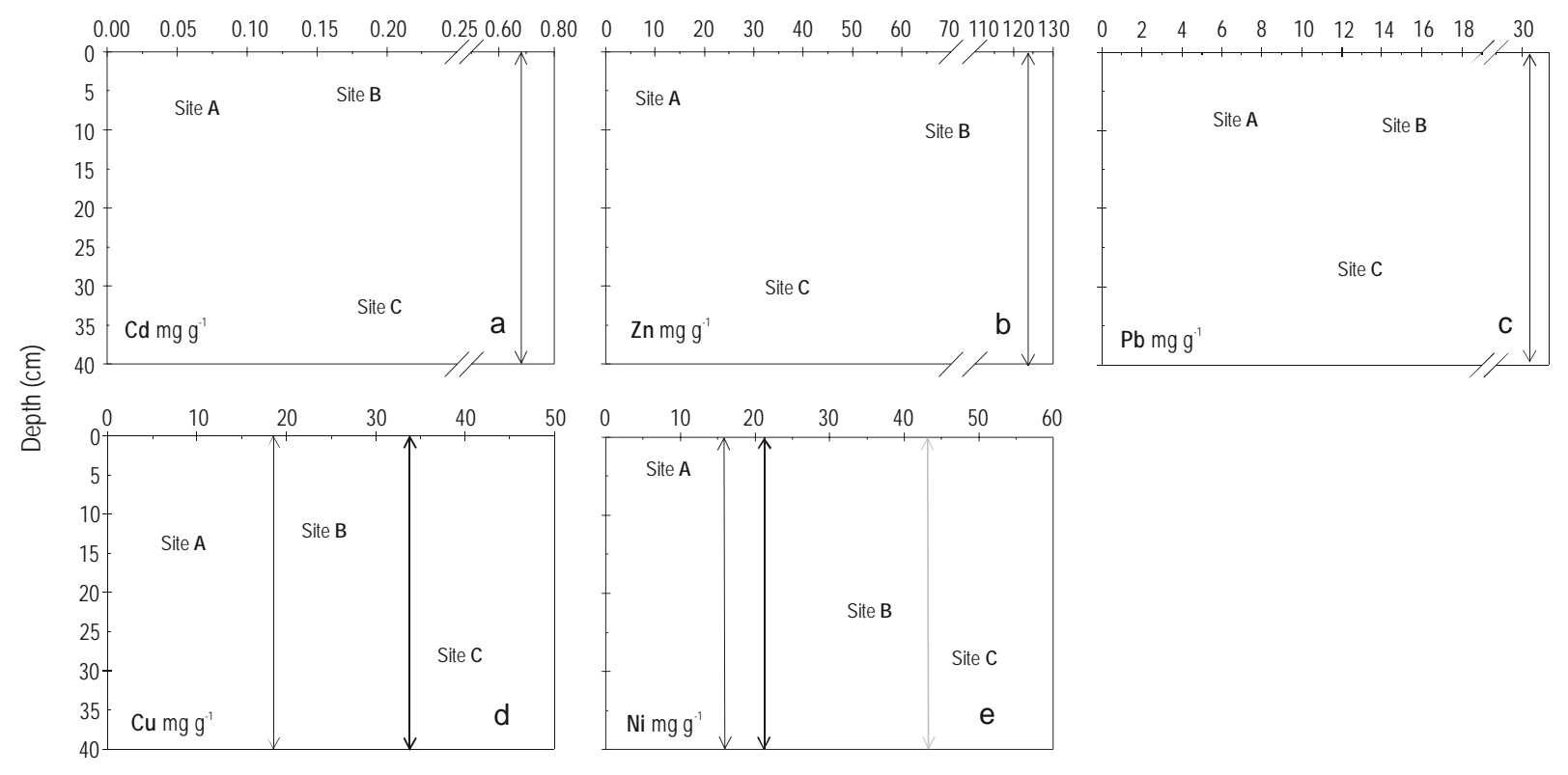

Figure 3. Vertical profiles of the concentrations of (a) $\mathrm{Cd}$, (b) $\mathrm{Zn},(\mathbf{c}) \mathrm{Pb},(\mathbf{d}) \mathrm{Cu}$ and (e) $\mathrm{Ni}$, in the sediments of sites $\mathrm{A}, \mathrm{B}$ and $\mathrm{C}$. The different arrows indicate the Threshold Effect Level $(T E L)(\uparrow)$, Effect Range Level (ERL) $(\uparrow)$ and Probable Effect Level (PEL) ( $\uparrow)$ proposed by NOAA in Screening Quick Reference Tables (Buchman, 1999).

Figura 3. Perfiles verticales de las concentraciones de (a) $\mathrm{Cd}$, (b) $\mathrm{Zn}$, (c) $\mathrm{Pb}$, (d) $\mathrm{Cu}$ y (e) $\mathrm{Ni}$, en los sedimentos de las estaciones $\mathrm{A}$, B y C. Las flechas indican el nivel de efecto umbral (TEL)( $\uparrow)$, nivel de intervalo de efecto (ERL) $(\uparrow)$ y el nivel de efecto probable (PEL) $(\uparrow)$ propuestos por la NOAA en las tablas de referencia para el monitoreo de sedimentos (Buchman, 1999). 
Table 4. Average partitioning coefficient $\left(K_{D}\right)$ in sediment from the Guadalete River estuary. The values obtained are compared to the partitioning coefficient of surface sediment from the Le An River, a freshwater system strongly affected by mining activities (Liu et al., 1999). Values are in $\mathrm{L} \mathrm{g}^{-1}$.

Tabla 4. Coeficientes de partición media $\left(K_{\mathrm{D}}\right)$ en sedimentos del estuario del Río Guadalete. Los valores obtenidos se comparan con el coeficiente de partición de sedimentos superficiales del Río Le An, un sistema de agua dulce fuertemente afectado por la actividad minera (Liu et al., 1999). Valores en $\mathrm{L} \mathrm{g}^{-1}$.

\begin{tabular}{lcccc}
\hline & $K_{\mathrm{D}, \mathrm{Cd}}$ & $K_{\mathrm{D}, \mathrm{Zn}}$ & $K_{\mathrm{D}, \mathrm{Cu}}$ & $K_{\mathrm{D}, \mathrm{Pb}}$ \\
\hline Site A & 0.272 & 0.321 & 0.610 & 0.426 \\
Site B & 0.181 & 1.110 & 1.365 & 0.513 \\
Site C & 0.376 & 2.000 & 3.302 & 0.494 \\
Le An River & $1.1 \sim 6.1$ & $1.5 \sim 7.7$ & $1.9 \sim 40.6$ & $2.9 \sim 9.9$ \\
\hline
\end{tabular}

for aerobic life. Except near the sediment-water interface, pore water in most coastal sediments is anoxic. However, these conditions are not lethal to benthic organisms because they develop strategies to obtain this oxygen and water-borne nourishment from the overlying water or they irrigate their environment with such water (O’Connor and Paul, 2000). So, if benthic organisms do not equilibrate with the pore water it is not correct to think that the bioavailability of heavy metals in the pore water is toxic.

\section{Diffusive fluxes}

The diffusive fluxes calculated for $\mathrm{Cd}, \mathrm{Pb}, \mathrm{Cu}$ and $\mathrm{Zn}$ by pore water profiles (table 5) indicated that the metals migrated downward into the sediment following a net deposition flow (table 6). Since the return diffusion flux is lower than the deposition or burial flux, the water column residential time of the metal decreases, thus decreasing the likelihood that the contaminant will be flushed out of the system and transported offshore. This is true for all sites and metals, except for $\mathrm{Pb}$ at site $\mathrm{C}$, where flux was negative, thus producing a net return diffusion flux. The order of magnitude of the estimated diffusive fluxes was $\mathrm{Zn}>\mathrm{Cu}=\mathrm{Pb}>\mathrm{Cd}$, though no significant differences were observed between $\mathrm{Cu}$ and $\mathrm{Pb}$ at site $\mathrm{A}$. The overall implication is that these sediments are an efficient trap for metals. Due to physical and biological processes, the magnitude of diffusive fluxes is associated with seasonal variability and an evaluation of these fluxes during the year is essential to determine the relative importance of sediment-water fluxes on the cycling of metals. Shine et al. (1998) reported that Cd and $\mathrm{Pb}$ were, respectively, more and less sensitive to changes in temperature. For this reason, the fluxes estimated here should be analyzed over more time (Yu et al., 2000).

In conclusion, the analysis of diffusive fluxes through the sediment-water interface demonstrated the efficiency of the estuarine sediment from Guadalete as sink for heavy metals. esas fases, capaz de enlazar metales, controlando, en particular, los equilibrios de partición para $\mathrm{Cd}, \mathrm{Cu}$ y $\mathrm{Pb}$ (Ankley et al., 1996). Las concentraciones de carbono orgánico particulado (POC) en el agua intersticial carcaterística de los sistemas estuáricos (Morris, 1985) podría explicar las altas concentraciones de $\mathrm{Cu}$ y $\mathrm{Pb}$ en muestras de agua intersticial sin filtrar.

\section{Biodisponibilidad y toxicidad}

Aunque se considere la gran biodisponibilidad de metales trazas en el agua intersticial, especialmente $\mathrm{Pb}$ y $\mathrm{Cu}$, esto no significa que el sedimento sea tóxico ya que los criterios de calidad para el agua no están expresados en base a la actividad, sino en una aproximación a esta condición (Valor Crónico Final), y un elevado número de experimentos sugieren que los efectos biológicos están correlacionados con la actividad del metal divalente, la única forma biodisponible (Ankley et al., 1996). Otra razón deriva de suponer la condición de equilibrio de los SQC. Esta teoría supone que el agua intersticial está en equilibrio con el sedimento. Si el sedimento es anóxico, y por tanto tóxico, el agua intersticial no satisface los criterios de calidad estándar. También con base en este hecho, en presencia de AVS no hay oxígeno disponible para la vida acuática aeróbica. Excepto en el agua intersticial próxima a la interfase agua-sedimento, la mayoría de los ecosistemas costeros son anóxicos. Sin embargo, estas condiciones no son letales para los organismos bentónicos ya que éstos desarrollan estrategias para obtener el oxígeno y el agua de la que obtienen el alimento, del agua sobrenadante, o bien establecen mecanismos de irrigación de su medio circundante con esta agua ( $\mathrm{O}^{\prime}$ Connor y Paul, 2000). Por tanto, si los organismos no se equilibran con el agua intersticial, no parece correcto pensar que la biodisponibilidad de los metales en el agua intersticial es responsible de la toxicidad.

Table 5. Porosity values $(\Phi)$, gradient concentrations of water-sediment interface $\left(\left|\frac{\partial \mathrm{C}}{\partial \mathrm{z}}\right|_{\mathrm{z}=0}, \mu \mathrm{g} \mathrm{L}^{-1}\right)$ and diffusion coefficients to infinite dilution for a temperature of $18^{\circ} \mathrm{C}\left(\mathrm{D}^{0}, \mathrm{~cm}^{2} \mathrm{~s}^{-1}\right)$ of $\mathrm{Cd}, \mathrm{Zn}, \mathrm{Cu}$ and $\mathrm{Pb}$.

Tabla 5. Valores de porosidad $(\Phi)$, gradientes de concentración en la interfase agua-sedimento $\left(\left|\frac{\partial \mathrm{C}}{\partial \mathrm{z}}\right|_{\mathrm{z}=0}, \mu \mathrm{g} \mathrm{L}^{-1}\right)$ y coeficientes de difusión a dilución infinita a $18^{\circ} \mathrm{C}$ de temperatura $\left(\mathrm{D}^{\circ}, \mathrm{cm}^{2} \mathrm{~s}^{-1}\right)$ del $\mathrm{Cd}, \mathrm{Zn}, \mathrm{Cu}$ y $\mathrm{Pb}$.

\begin{tabular}{lrrrrr}
\hline & & \multicolumn{3}{c}{$\left|\frac{\partial \mathrm{C}}{\partial \mathrm{z}}\right|_{\mathrm{z}=0}$} \\
\cline { 3 - 6 }$\Phi(\mathrm{z}=0)$ & \multicolumn{1}{c}{$\mathrm{Cd}^{2+}$} & \multicolumn{2}{c}{$\mathrm{Zn}^{2+}$} & $\mathrm{Cu}^{2+}$ & \multicolumn{1}{c}{$\mathrm{Pb}^{2+}$} \\
\hline Site A & 0.142 & 0.34 & 35.10 & 9.46 & 6.42 \\
Site B & 0.416 & 0.94 & 35.20 & 13.01 & 15.36 \\
Site C & 0.679 & 0.25 & 23.30 & 6.13 & -18.77 \\
\hline & $\mathrm{D}^{\circ} \times 10^{6}$ & 6.03 & 6.13 & 5.88 & 7.95 \\
\hline
\end{tabular}


Table 6. Diffusive fluxes of $\mathrm{Cd}, \mathrm{Zn}, \mathrm{Cu}$ and $\mathrm{Pb}\left(\mu \mathrm{g} \mathrm{cm}{ }^{-2} \mathrm{yr}^{-1}\right)$ for the study area and comparison with other data obtained for a near coastal site (Caño S. Petri), located in the southern part of Cádiz Bay (Ponce et al., 2000).

Tabla 6. Flujos difusivos de $\mathrm{Cd}, \mathrm{Zn}, \mathrm{Cu}$ y $\mathrm{Pb}\left(\mu \mathrm{g} \mathrm{cm}^{-2}\right.$ año-1) en el área de estudio y comparación con otros datos obtenidos por un sitio casi costero (Caño S. Petri), localizado en la parte sur de la Bahía de Cádiz (Ponce et al., 2000).

\begin{tabular}{lcccc}
\hline & Cd & Zn & $\mathrm{Cu}$ & $\mathrm{Pb}$ \\
\hline Site A & 0.004 & 0.466 & 0.120 & 0.111 \\
Site B & 0.040 & 1.518 & 0.538 & 0.859 \\
Site C & 0.019 & 1.826 & 0.461 & -1.908 \\
Caño S. Petri & $-0.002 \sim-0.095$ & $-0.20 \sim-0.54$ & $-0.78 \sim-37.78$ & $-0.15 \sim-2.45$ \\
\hline
\end{tabular}

As proposed by SQC, even if the ratio between SEM and AVS is smaller than one, these should not be used as the only criteria to establish toxicity. Evidence that $\mathrm{Cu}$ and $\mathrm{Pb}$ concentrations are higher than the Threshold Effect Levels proposed by NOAA seems to indicate that further studies are necessary, with both benthic and pelagic organisms, in order to evaluate the real bioavailability and bioaccumulation of trace metals, and to test acute and chronic toxicity and whether this is caused by metals or other chemicals.

\section{Acknowledgements}

This work was carried out within the framework of the project Estudio de las Comunidades Acuáticas del Estuario del Río Guadalete y su Función como Zona de Cría de Especies Marinas, funded by the Consejería de Medio Ambiente (Xunta de Andalucía).

\section{References}

Ankley, G.T., Di Toro, D.M., Hansen, D.J. and Berry, W.J. (1996). Technical basis and proposal for deriving sediment quality criteria for metals. Environ. Toxicol. Chem., 15(12): 2056-2066.

Boothman, W.S. and Helmstetter, A. (1992). Vertical and seasonal variability of acid volatile sulfides in marine sediments. Final Research Rep., US Environmental Protection Agency, Narragansett, RI.

Buchman, M.F. (1999). NOAA Screening Quick Reference Tables. NOAA HAZMAT Report 99-1, Seattle, WA. Coastal Protection and Restoration Division, National Oceanic and Atmospheric Administration.

Chapman, P.M. (1995). Ecotoxicology and pollution-key issues. Mar. Pollut. Bull., 31: 167-177.

Di Toro, D.M., Mahony, J.D., Hensen, D. and Berry, W.J. (1996). A model of the oxidation of iron and cadmium sulfide in sediments. Environ. Toxicol. Chem., 15(12): 2168-2186.

Gonzalez, A.M. (1996). A laboratory-formulated sediment incorporating synthetic acid-volatile sulfide. Environ. Toxicol. Chem., 15(12): 2209-2220.

Langston, W.J. and Spence, S.K. (1994). Metal analysis. In: P. Calow (ed.), Handbook of Ecotoxicology. Vol. 2. Blackwell Sci. Publ., pp. 45-78.

Li, Y.H. and Gregory, S. (1974). Diffusion of ions in sea water and in deep-sea sediments. Geochim. Cosmochim. Acta, 38: 703-714.

Liu, W., Wang, Z., Wen, X. and Tang, H. (1999). The application of preliminary sediment quality criteria to metal contamination in the Le An River. Environ. Pollut., 105: 355-366.

\section{Flujos difusivos}

Se calcularon los flujos difusivos en los perfiles de agua intersticial para $\mathrm{Cd}, \mathrm{Pb}, \mathrm{Cu}$ y Zn (tabla 5). Éstos indicaron que los metales migraban hacia el interior del sedimento, produciéndose un flujo neto de depositación (tabla 6). Como el flujo difusivo de retorno es menor que el de depositación, el tiempo de residencia de los metales en la columna de agua disminuye, disminuyendo también la probabilidad de que los metales puedan ser transportados hacia el exterior del sistema. Esto es así para todas las estaciones y metales, excepto en el caso de la estación $\mathrm{C}$ para el $\mathrm{Pb}$, donde el flujo es negativo, produciendo en consecuencia un retorno mediante flujos difusivos. El orden de magnitud para los flujos difusivos fue $\mathrm{Zn}>\mathrm{Cu}=\mathrm{Pb}>\mathrm{Cd}$, aunque no se observan diferencias entre $\mathrm{Cu}$ y $\mathrm{Pb}$ para la estación A. El análisis global de los resultados pone de manifiesto que los sedimentos son una trampa eficiente para los metales. Debido a los procesos físicos y biológicos, la magnitud de los flujos difusivos depende de la variación estacional, y su evaluación durante el periodo anual es esencial a la hora de determinar la importancia relativa de estos flujos en la biogeoquímica de los metales. Shine et al. (1998) han manifestado que $\mathrm{Cd}$ y $\mathrm{Pb}$ eran, respectivamente, más y menos sensibles a los cambios de temperatura. Por tanto, los flujos estimados deben ser analizados a lo largo del tiempo (Yu et al., 2000).

En conclusión, los análisis de los flujos difusivos a través de la interfase agua-sedimento demostraron la eficacia de los sedimentos del Estuario del Río Guadalate como sumidero para metales. Como proponen los SQC, aun cuando la proporción entre SEM y AVS es menor que 1 éstos no pueden emplearse como únicos criterios para establecer la toxicidad. $\mathrm{La}$ evidencia de que las concentraciones de $\mathrm{Cu}$ y $\mathrm{Pb}$ son superiores a los TELs propuestos por NOAA, parecen indicar que se requieren estudios en profundidad con organismos pelágicos y bentónicos con el fin de evaluar la biodisponibilidad real y la acumulación de los metales trazas, así como realizar ensayos de toxicidad aguda y crónica para determinar si esta toxicidad tiene su origen en los metales o en otros compuestos químicos.

\section{Agradecimientos}

Este trabajo ha sido desarrollado en el marco del proyecto Estudio de las Comunidades Acuáticas del Estuario del Río 
Loring, D.H. and Rantala, R.T.T. (1992). Manual for the geochemical analysis of marine sediments and suspended particulate matter. Earth Sci. Rev., 32: 235-283.

Morris, A.W. (1985). Estuarine chemistry and general survey. In: P.C. Head (ed.), Practical Estuarine Chemistry: A Handbook. Cambridge Univ. Press, Cambridge, pp. 1-60.

O’Connor, T.P. and Paul, J.F. (2000). Misfit between sediment toxicity and chemistry. Mar. Pollut. Bull., 40(1): 59-64.

Peterson, G.S., Ankley, G.T. and Leonard, E.N. (1996). Effect of bioturbation on metal-sulfide oxidation in surficial freshwater sediments. Environ. Toxicol. Chem., 15(12): 2147-2155.

Ponce, R., Forja, J.M. and Gómez-Parra, A. (2000). Influencia de la actividad antropogénica en la distribución vertical de $\mathrm{Zn}, \mathrm{Cd}, \mathrm{Pb}$ y $\mathrm{Cu}$ en agua intersticial y sedimentos marinos costeros (Bahía de Cádiz, SW de España). Cienc. Mar., 26(3): 479-502.

Shine, J.P., Ika, R. and Ford, T.E. (1998). Relationship between oxygen consumption and sediment-water fluxes of heavy metals in coastal marine sediments. Environ. Toxicol. Chem., 17(11): 2325-2337.

Simpson, S.L. (2001). A rapid screening meted for acid-volatile sulfide in sediments. Environ. Toxicol. Chem., 20(12): 26572661.
Guadalete y su Función como Zona de Cría de Especies Marinas, financiado por la Consejería de Medio Ambiente (Xunta de Andalucía).

Traducido al español por los autores.

Sweerts, J.P.R.A., Baer-Gilissen, M.J. and Cornelese, A.A. (1991). Oxygen-consuming processes at the profundal and littoral sediment-water interface of a small meso-eutrophic lake (Lake Vechten, The Netherlands). Limnol. Oceanogr., 36: 1124-1133.

Yu, K.C., Lam, M.H.W., Yen, Y.F. and Leung, A.P.K. (2000). Behavior of trace metals in the sediment pore waters of intertidal mudflats of a tropical wetland. Environ. Toxicol. Chem. 19(3): 535-542.

Yu, K.C., Tsai, L.J., Chen, S.H. and Ho, S.T. (2001). Chemical binding heavy metals in anoxic river sediments. Water Res., 35(17): 4086-4094. 